\title{
Current status of plant pathogens of agricultural importance for Colombia. A review
}

\section{Estado actual de fitopatógenos de importancia agrícola para Colombia. Una revisión}
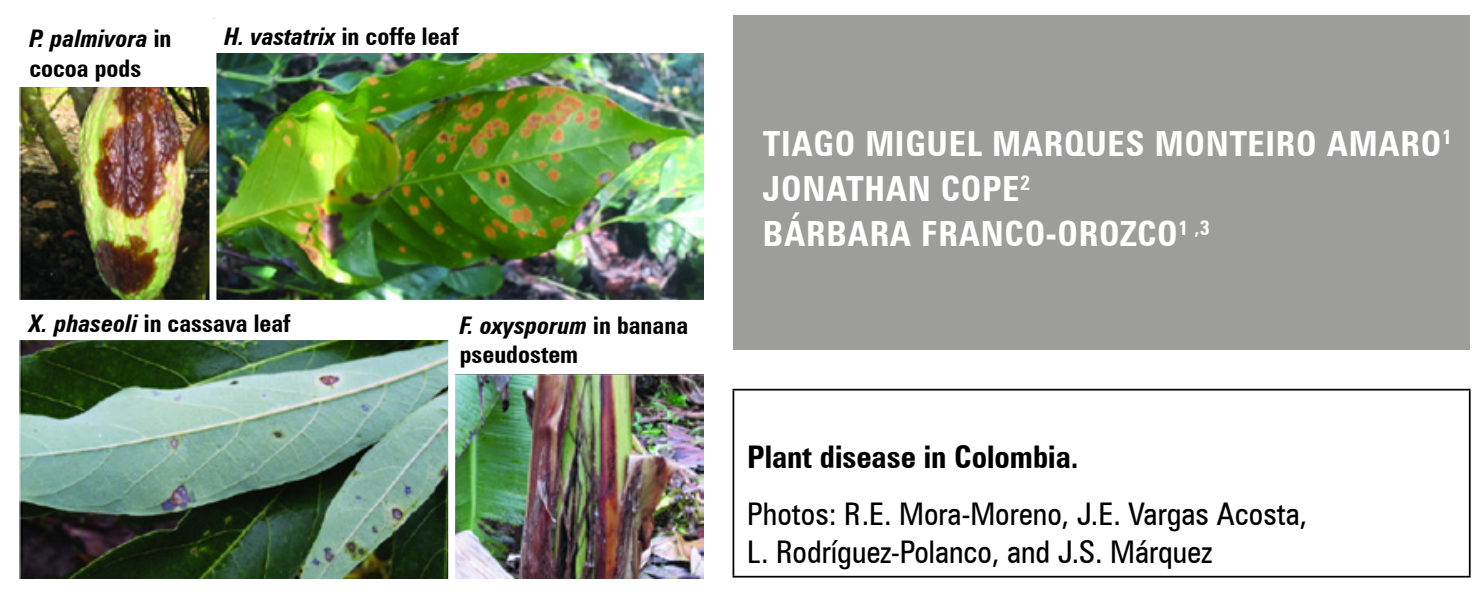

\section{ABSTRACT}

Plant disease still plays a major role in limiting agricultural production worldwide. Pathogens and pests reduce crop yield and can cause large reductions in crop quality. Colombia is no exception as it contends with many devastating pathogens that present a major threat to the country's agricultural sector. This review is important because it highlights four of the more damaging pathogens that affect the economics of important crops in Colombia - Xanthomonas phaseoli pv. manihotis (Xpm), Fusarium oxysporum f. sp. cubense (Foc), Phytophthora palmivora, and Hemileia vastatrix. This paper was based on an extensive literature search for plant diseases in Colombia in databases such as PubMed and Google Scholar. Moreover, this search was complemented with research on crop production in the country in databases made available by the Food and Agriculture Organization of the United Nations (FAO). The four pathogens reviewed in this paper were chosen not only because of their current devastating effects on Colombia's agricultural production but also because of their potential to cause further damage in the near future. Understanding the current situation of these crop pathogens in Colombia is imperative for state directives aimed at developing informed and efficient control strategies.

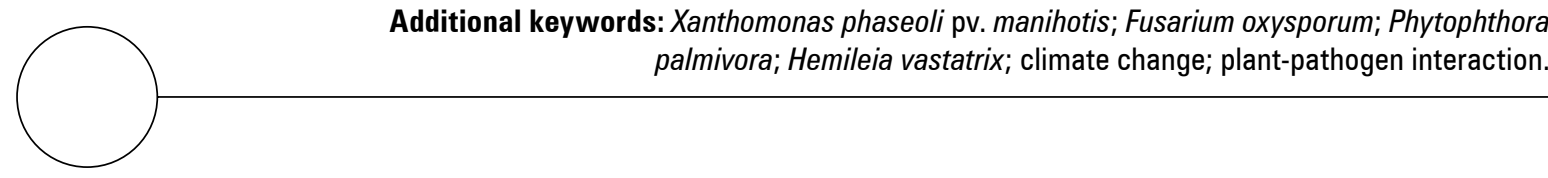

\footnotetext{
1 Tecnológico de Antioquia - Institución Universitaria, Facultad de Ingeniería, Medellin (Colombia). ORCID Amaro, T.M.M.M.: 0000-0002-1483-5805; ORCID Franco-Orozco, B.: 0000-0002-8215-5596

2 The James Hutton Institute, Dundee (United Kingdom). ORCID Cope, J.: 0000-0003-1540-9768

3 Corresponding author. bfranco.orozco1205@gmail.com
} 


\section{RESUMEN}

Las enfermedades de las plantas constituyen todavía un gran factor limitante para la producción agrícola a nivel global. Los patógenos y plagas vegetales disminuyen el rendimiento agrícola y pueden causar grandes reducciones en la calidad de los cultivos cosechados. Colombia no es una excepción, ya que lucha contra muchos fitopatógenos devastadores que representan una gran amenaza para el sector agrícola del país. Este artículo de revisión es importante ya que destaca cuatro de los fitopatógenos más devastadores que afectan económicamente cultivos de gran importancia en Colombia - Xanthomonas phaseoli pv. manihotis (Xpm), Fusarium oxysporum f. sp. cubense (Foc), Phytophthora palmivora, y Hemileia vastatrix. Este trabajo fue desarrollado a través de una búsqueda extensiva de literatura acerca de enfermedades vegetales en Colombia en bases de datos como por ejemplo PubMed y Google Scholar. Además, esta búsqueda fue complementada con un rastreo acerca de la producción agrícola del país en bases de datos que se encuentran disponibles por la Organización de las Naciones Unidas para la Alimentación y la Agricultura (FAO). Los cuatro patógenos descritos en este trabajo fueron elegidos no solamente por sus actuales efectos devastadores en la producción agrícola colombiana pero también por su potencial para causar aún más daño en un futuro cercano. El entendimiento de la situación actual de estos fitopatógenos en Colombia es esencial para que se implementen políticas públicas que promuevan el desarrollo de nuevas estrategias de control eficientes e informadas.

Palabras clave adicionales: Xanthomonas phaseoli pv. manihotis; Fusarium oxysporum; Phytophthora palmivora; Hemileia vastatrix; cambio climático; interacción planta-patógeno.

Received: 30-01-2021 Accepted: 04-03-2021 Published: 26-04-2021

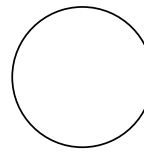

The diverse climates and topographies of Colombia allow for the cultivation of a wide variety of crops, including maize, coffee, rice, plantain, sugarcane, cassava, fruit trees, potato, African oil palm, common bean, cocoa, cotton, sorghum, banana, vegetables, and flowers (Hudson, 2010; Lau et al., 2013). In 2013, these agricultural activities generated $5.2 \%$ of Colombia's gross domestic product (GDP), with agricultural products accounting for approximately $11 \%$ of total exports. The importance of agriculture to the Colombian economy is best exemplified by employment in the agricultural sector, which accounted for $17.5 \%$ of the jobs in Colombia in 2013 (OECD, 2015).

Despite this clear importance, the weight of agriculture in the Colombian economy is falling, from 16.5\% of the GDP in 1990 to $5.2 \%$ in 2013 (OECD, 2015). While this can mean improved economic activities in other sectors, there is cause for concern when looking at the export-to-import ratio. In 1990, there was a trade surplus of USD $\$ 2.4$ billion for Colombian agriculture; however, by 2013, this value decreased to USD $\$ 0.5$ billion. Furthermore, crop production has decreased from $62 \%$ of Colombia's total agricultural production in 1990, to $59 \%$ in 2013 - corresponding to decreases in Colombian agricultural land usage from 45 to 43 million ha over the same period (OECD,
2015). The cause of this relative decrease in the importance of Colombian agriculture to the economy is complex and multi-faceted. One solution for current challenges faced by the Colombian agricultural sector would be to increase the production potential of current agricultural lands.

Plant pests and diseases are major threats to reaching food security worldwide (Oerke, 2006; Donatelli et al., 2017). Food security was described by the United Nations world food summit as "when all people, at all times, have physical and economic access to sufficient, safe and nutritious food that meets their dietary needs and food preferences for an active and healthy life" (FAO, 2006; Chakraborty and Newton, 2011). Hence, the development and implementation of efficient and sustainable crop protection strategies against pests and pathogens is crucial. The development of these strategies is more urgent because of climate change, which will have a direct impact on the incidence of pests and diseases in crops (Ávila and Romero, 2017; Raza et al., 2019).

To be able to effectively deploy strategies to fight plant pests and diseases in the field, a profound understanding of the pathogen's biology and interaction with plant hosts is essential. Hence, several 
studies have been conducted that aimed to increase understanding of the mechanisms involved in a diverse range of plant diseases (Dean et al., 2012; Mansfield et al., 2012; Kamoun et al., 2015). However, most studies focused on pathogens of economic importance to the developed world. Whereas, pathogens that affect crops in tropical areas, mainly in developing countries, are repeatedly neglected. This situation is made more problematic by the fact that crops in the tropics have double the losses of crops in temperate zones (Drenth and Guest, 2016). Thus, more studies focused on plant diseases in tropical regions are of paramount importance.

This paper was based on an extensive literature search for plant diseases in Colombia in databases such as PubMed and Google Scholar in 2020. Several search words were used, including "plant disease", "Colombia", and "crop yields", among others. After the pathogens were selected, individual searches were performed for each pathogen and crop in the same databases. For the pathogens, all articles mentioning these diseases in Colombia were read and considered for this review. This paper describes pathogens that are likely to cause immense damage to four crops of high economic importance in Colombia in the near future. These pathogens are: Xanthomonas phaseoli pv. manihotis affecting cassava, Fusarium oxysporum f. sp. cubense (Foc) affecting banana, Phytophthora palmivora affecting cacao, and Hemileia vastatrix affecting coffee. Xpm was reviewed because it causes large losses in cassava production, reaching $57 \%$ losses in susceptible cassava cultivars (Fanou et al., 2018). This is highly problematic because Colombia is the fourth biggest producer of this crop in the Americas (1.0 million tons) (FAO, 2019). Foc was mentioned because of the arrival to Colombia of a new race (Tropical Race 4) that has had catastrophic effects on banana production in other parts of the world. This pathogen could have a huge impact on Colombia in terms of banana and plantain production, which accounts for $20.6 \%$ of Colombian agriculture production (Lau et al., 2013). $P$. palmivora was chosen because of the social importance that cocoa production has for populations that previously produced illegal cocaine. While there is little information on the effects of this pathogen on cocoa production, it was shown that $P$. palmivora consistently caused cocoa losses of more than $70 \mathrm{~kg} \mathrm{ha}^{-1}$ year ${ }^{-1}$ (valued at approximately USD\$82.6) (Ramírez, 2016). Finally, $H$. vastatrix was chosen because of its large impact on coffee production, the most valuable agricultural product in Colombia (coffee), accounting for $17.3 \%$ of the countries agricultural value (Lau et al., 2013; FAO, 2018).

The reason each pathogen was selected is detailed, along with a summary of current knowledge on their biology. Moreover, each pathogen has a proposed new method of control that could and should be used in the field in Colombia. This review compiles a range of relevant information for those seeking to control tropical pathogens efficiently and intelligently in the field. The hope is it will motivate new studies on these devastating pathogens, not only in Colombia but also in all countries with similar tropical climates.

\section{XANTHOMONAS PHASEOLI PV. MANIHOTIS}

The genus Xanthomonas includes a large number of gram-negative phytopathogenic bacteria that are able to infect a huge number of hosts (Hayward, 1993; Ryan et al., 2011; Marin et al., 2019), including economically important crops such as rice (Zhang and Wang, 2013), citrus (Bansal et al., 2017), tomato (Abrahamian et al., 2019), and banana (Ocimati et al., 2019). The genus Xanthomonas comprises 27 species, with each individual species being divided into pathovars that can exhibit host and/or tissue specificities (Ryan et al., 2011). This review focused on Xanthomonas phaseoli pv. manihotis (Xpm) because of its devastating effects on cassava in Colombia.

Cassava (Manihot esculenta Crantz) is an important crop in tropical regions, where it represents the staple food for more than 600 million people (López and Bernal, 2012; Lin et al., 2019). Because of its inherent drought tolerance, cassava's importance as a staple crop is predicted only to increase with climate change, better adapting to the changing climatic conditions (Jarvis et al., 2012). Cassava is an important crop for Colombian agriculture, ranked fourth for cassava producing countries in the Americas at 1.0 million tons in 2019 - only surpassed by Brazil (17.4 million tons), Paraguay (3.3 million tons) and Perú (1.2 million tons) (FAO, 2019). Additionally, cassava accounted for $9.3 \%$ of Colombian agricultural production and 4\% of the agricultural value in 2013 (Lau et al., 2013). Despite this, the importance of cassava production in Colombia is decreasing, representing only $6.2 \%$ of the Colombian agricultural production in 2018 (FAO, 2018). This is reflected in yields that were reduced to an average production yield of $12.4 \mathrm{t}$ $\mathrm{h}^{-1}$ year ${ }^{-1}$, as compared to yields as high as $37 \mathrm{t} \mathrm{ha}^{-1}$ year $^{-1}$ (Howeler et al., 2013; DANE, 2016). Several 
aspects have contributed to this reduced production yield, one being the prevalence of diseases in cassava, such as Xpm (Howeler et al., 2013).

The bacterial agent $\mathrm{Xpm}$ is responsible for the disease called cassava bacterial blight (CBB), which is a major cassava disease along with the cassava mosaic disease and cassava brown streak disease (Lin et al., 2019). The first reported case of CBB was in Brazil in 1912 (Fanou et al., 2018), and it now affects cassava production in all production zones worldwide (Fanou et al., 2018; Lin et al., 2019). In Colombia, CBB disease is highly prevalent within endemic zones, being found in the Colombian regions: eastern planes, northern coast, and Cauca (Trujillo et al., 2014; Cadavid, 2006; Álvarez, 2006). Crop losses from CBB vary considerably but can be significantly damaging (Verdier et al., 2004), with reported yield losses of $57 \%$ in susceptible cassava cultivars (Fanou et al., 2018). In addition to yield losses, CBB has reduced the nutritional value of cassava tubers and leaves (Obigbesan and Matuluko, 1976).

The symptoms of $\mathrm{CBB}$ disease are diverse and include angular leaf lesions, blight, wilt, stem exudates, and stem canker (Fig. 1; Mansfield et al., 2012). The disease cycle of $\mathrm{CBB}$ is thought to begin in the rainy seasons with the development of Xpm as an endophyte in leaves (Boher and Verdier, 1994). After this phase, Xpm enters the plant via stomata or wounds, reaching the vascular tissue of the plant where it can move systematically. Ultimately, Xpm blocks plant veins, causing the disease symptoms described above (Boher and Verdier, 1994; López and Bernal, 2012). Disease spreads when Xpm is dispersed from plant to plant via splashing raindrops and between fields by
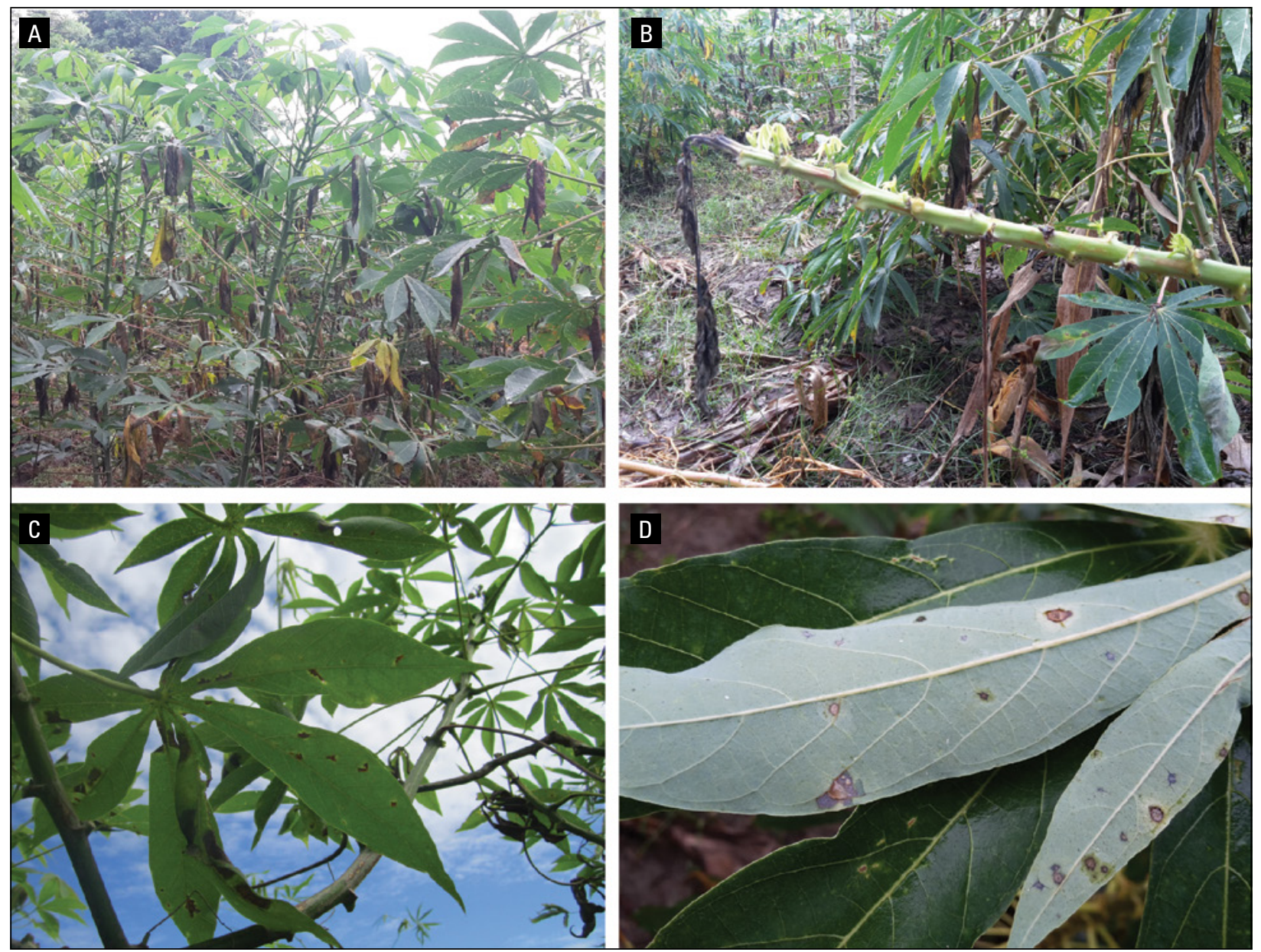

Figure 1. Symptoms of Xanthomonas axonopodis pv. Manihotis (Xam) infection in cassava plants grown in Colombia. A, extensive leaf necrosis; B, stem rot and wilt; C and D, angular leaf lesions. Source: R.E. Mora-Moreno, Universidad Nacional de Colombia, Bogota. 
infected propagative material (Lozano and Sequeira, 1974; Lozano, 1986; López and Bernal, 2012).

Several procedures have been used to try to control CBB in the field. Better cultural practises (crop rotations, use of clean planting material, choice of planting times, and pruning above-ground plant material) and improved sanitary control of plant material transport, coupled with planting more resistant cassava varieties, were shown to decrease or even eradicate $\mathrm{CBB}$ in some Colombian regions (Lozano, 1986). Additionally, biological control strategies have been suggested, with foliar applications of Pseudomonas spp., which reduces $\mathrm{CBB}$ disease symptoms in cassava plants (Lozano, 1986; Hernandez et al., 1986; Marin et al., 2019). However, foliar applications have only been tried in a small number of studies for cassava (Marin et al., 2019), possibly because of environmental concerns. Despite these practises being used for decades, this disease is still reducing cassava production worldwide. Cultural and sanitary practises are crucial but are insufficient alone, and biological control options are still in the developmental stages. Thus, the use and generation of more resistant cassava cultivars is the best option to face the challenges posed by Xpm for the immediate future (López and Bernal, 2012).

The use of resistant cultivars is widely regarded as the most viable approach to reducing Xpm infections (Restrepo et al., 2000; Álvarez, 2006; López and Bernal, 2012). Resistance to Xpm originated from crosses with the wild relative of cassava, $M$. glaziovii (Fanou et al., 2018), and has been quantitative in nature. The resistance levels acquired have been associated with general plant defence mechanisms that limit colonisation of the xylem, such as lignification, callose deposition, suberization, accumulation of phenolic compounds, and vessel occlusion (Kpemoua et al., 1996; Jorge et al., 2000). In recent years, several QTLs have been found to be connected to Xam resistance in cassava, with specific genes linked to CBB resistance (Soto et al., 2017; Fanou et al., 2018; Herrera et al., 2018; Díaz et al., 2018). These discoveries open potential new possibilities by incorporating these OTLs and genes into varieties with desired genetic backgrounds. Additionally, the use of several OTLs simultaneously - known as gene pyramiding - may achieve more effective and durable resistance (Fanou et al., 2018).
Despite the prospects of resistance gene transfer, the management of Xpm under field conditions remains incredibly challenging for two main reasons: pathogen genetic variability and the sporadic nature of Xpm infections. Genetic variability has been repeatedly reported across Xpm field isolates, yet it remains difficult to connect this variability to variations in disease severity in the field (Restrepo et al., 2000; Restrepo et al., 2004; Wydra et al., 2004; Lin et al., 2019). This lack of understanding linking the genetic variability of Xpm to its pathogenicity makes finding durable genetic resistances to control CBB a very ambitious goal (Lin et al., 2019). The other hurdle for managing Xpm is the lack of understanding of conditions that favour $X p m$ infections. It is clear that some environmental conditions trigger highly severe $\mathrm{CBB}$, but these conditions are still poorly understood (Lin et al., 2019), making the cultural practices mentioned above difficult to apply efficiently. An increased understanding of Xpm biology is imperative for developing durable controls under field conditions.

Many gram-negative pathogenic bacteria release effector molecules aimed at subverting host immunity and enhancing pathogen colonization - via a type III secretion system (Büttner and He, 2009). Correspondingly, Xpm has been shown to successfully deploy these effectors in large numbers (Bart et al., 2012; Arrieta-Ortiz et al., 2013; Medina et al., 2017). Thus, further research on the conserved and virulence determinant effector molecules in Xpm could play an important role in the search for durable resistance to this pathogen (Chavarriaga-Aguirre, 2016; Medina et al., 2017). In addition to studies on effector biology, it is critical to deploy strategies to monitor Xpm field populations. A study by Bernal-Galeano et al. (2018) describes a promising strategy using multiplex nested PCRs to detect Xpm under field conditions regardless of the strain virulence. Additionally, another recent study developed a detection method for Xpm based on a variable number of tandem repeat analyses (MLVAs), obtaining reproducible results (Rache et al., 2019). The deployment of these new methods could greatly increase the amount of available information for Xpm population dynamics, allowing the application of improved disease management strategies in the near future.

In summary, cassava is an important food crop for Colombia and other tropical countries, and this importance is predicted to increase in coming years 

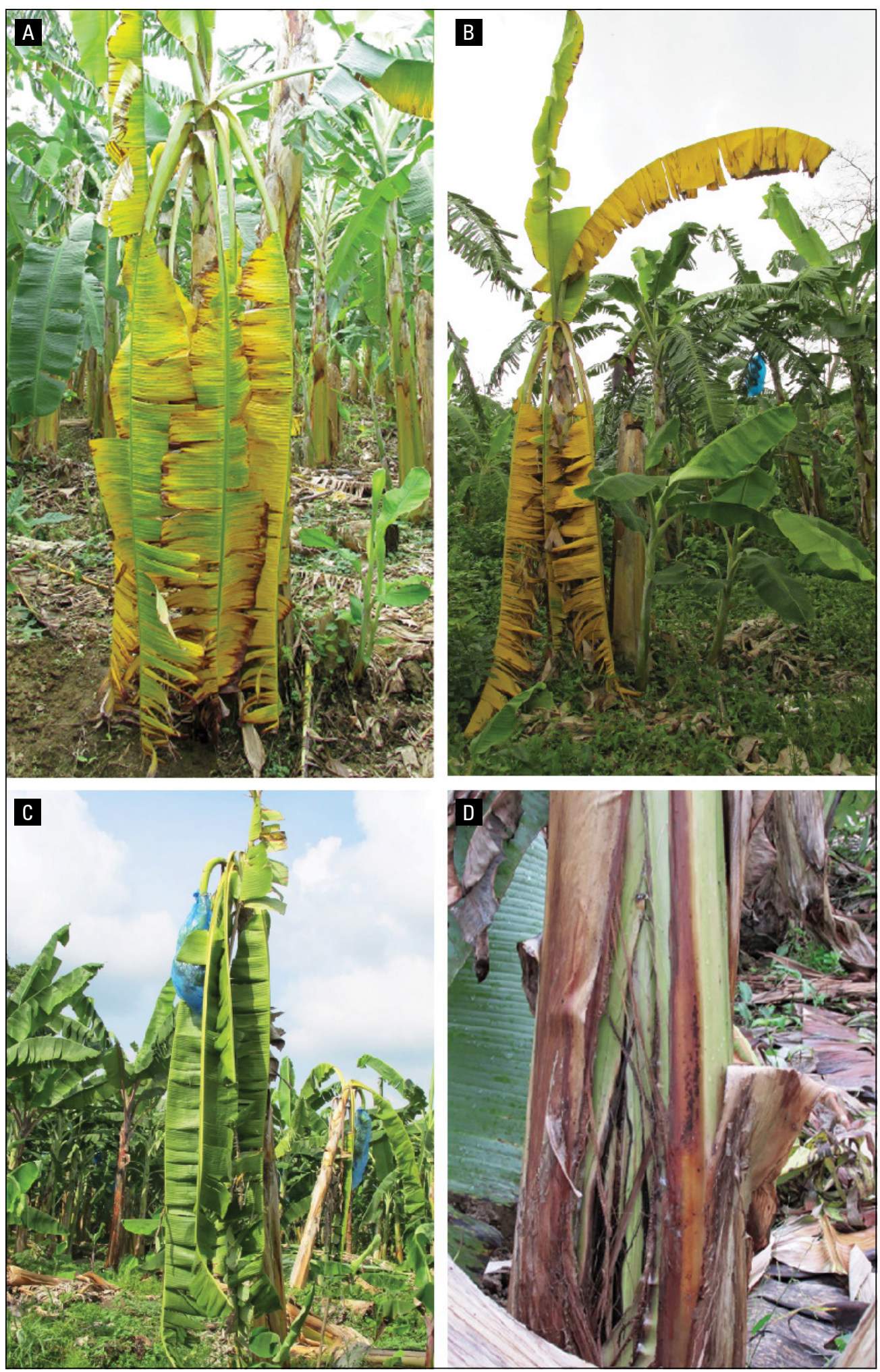

Figure 2. Symptoms of Fusarium oxysporum f. sp. cubense (Foc) race 1 and race 2 infections in banana plants grown in Colombia. A, B and C, yellowing and wilting of leaves; D, vascular discolouration of the pseudostem, shown with a longitudinal cut. Source: J.E. Vargas Acosta, Banana Research Center (CENIBANANO). 
because of climate change (Jarvis et al., 2012). However, the production of cassava is greatly reduced by crop losses associated with Xpm infections. This is in part due to our limited knowledge on Xpm biology, despite some valuable efforts from the scientific community (Lin et al., 2019). Thus, it is critical that more $X p m$ research is conducted to control the damage that this devastating pathogen produces in cassava fields in Colombia and worldwide.

\section{FUSARIUM OXYSPORUM}

The genus Fusarium comprises several fungal species, distributed worldwide, that are mostly known for being plant pathogenic and for producing mycotoxins that contaminate human and animal food (Di Pietro et al., 2003).

In the Fusarium genus, the most common species is F. oxysporum (Lombard et al., 2019). Diverse F. oxysporum strains can infect a wide variety of host plants, including most cultivated crops - with the exception of grasses and trees. This article focused on Fusarium oxysporum f. sp. cubense (Foc) (also known as Fusarium odoratissimum) (Maryani et al., 2019) because of the immense threat that this pathogen poses to banana and plantain (Musa spp.) production in Colombia and worldwide (Dita et al., 2018).

Bananas and plantains are grown in over 135 countries, producing a reported total of 148 million tons in 2016, making banana the most produced fruit on earth (Dusunceli, 2017; Bubici et al., 2019). Bananas are a staple food for over 400 million people worldwide, and this number is predicted to increase because climate change will increase the productive area of bananas in subtropical and tropical highlands (Bubici et al., 2019). Since 2005, banana cultivation has been of high economic importance in Colombia, ranked as the $10^{\text {th }}$ largest producer and the $3^{\text {rd }}$ largest exporter worldwide (Hudson, 2010). Banana and plantain production accounted for $20.6 \%$ of Colombian agriculture production, generating $14.2 \%$ of its value in 2013 (Lau et al., 2013). This importance can still be observed in data from 2018, where bananas represented $10.4 \%$ of the agricultural production in Colombia (FAO, 2018).

The fungal agent Foc is responsible for the devastating banana and plantain disease commonly known as Panama disease (Ordonez et al., 2015; Ploetz, 2015a). Foc has been divided into four different pathogenic races according to their host range, including Race 1
(Foc 1), Race 2 (Foc 2), Race 3 (Foc 3) and Race 4 (Foc 4) (Oin et al., 2017). In the early $20^{\text {th }}$ century, this disease devastated banana plantations worldwide, which relied almost completely on the banana cultivar Gros Michele. However, this cultivar was susceptible to Foc (Race 1), causing billions of dollars of economic damage and critical social problems. By the second half of the $20^{\text {th }}$ century, almost all banana production shifted to the Cavendish cultivar, which is resistant to Foc (Ploetz, 2005). Because of the spread of the Cavendish variety, Foc stopped posing a serious immediate threat to banana production (Dita et al., 2018). However, in the 1990s, a new race of Foc, capable of infecting Cavendish bananas, was identified and named tropical Race 4 (TR4). For some decades, TR4 could only be found in east Asia and northern Australia, but recently it has spread throughout Asia and has been identified in Africa (Mozambique) and South America (Colombia) (Dita et al., 2018; Graham, 2019; García-Bastidas et al., 2020). The strain Foc TR4 is capable of infecting $80 \%$ of the banana and plantain cultivars currently in use (Ploetz, 2006). Therefore, it is expected that the spread of Foc TR4 will have devastating consequences for banana production and dependent populations - particularly in countries that produce and export bananas, such as Colombia (Ploetz, 2015b; García-Bastidas et al., 2020).

The lifecycle of Foc is extremely versatile, with many characteristics that make control in the field extremely challenging. Firstly, Foc is a soil-born fungus that can persist in soil for more than twenty years in the form of chlamydospores, even in the absence of its primary host (Dita et al., 2018). Moreover, this pathogen has been shown to grow as hyphae in organic residues and to survive as an endophyte in various non-host plants (Hennessy et al., 2005; Pegg et al., 2019). Therefore, significant reductions in Foc levels will be difficult in extensive banana plantations with conventional cultural practices (such as crop rotations and use of cover crops) (Zhang et al., 2013; Pattison et al., 2014; Wang et al., 2015; Thangavelu et al., 2020).

Infection of new material occurs once Foc chlamydospores perceive the presence of host plants with exudates or by contact with root tissues. They then germinate and start the infection process by entering secondary or tertiary feeder roots (Dita et al., 2018). After entering the root system, Foc quickly spreads within the host plant, with its growth resulting in extensive blockage of the plant's xylem vessels, exhibiting the characteristic phenotypes of yellowing 
and wilted leaves (Fig. 2; Pegg et al., 2019; Thangavelu et al., 2020). This growth inside the plant vascular system also poses an additional hurdle when trying to control Foc using chemical and biological methods. After infection, Foc spreads between plants via root proximity or water dispersal, and, because of global communication and commerce, it can travel between different fields, countries, and even continents (Dita et al., 2018; Pegg et al., 2019). Thus, it is of paramount importance that countries and regions with low incidences of Foc TR4 implement strict exclusion and containment measures to contain this pathogen.

Analysis of the Foc lifecycle shows why the control of this pathogen is extremely difficult; nonetheless, several strategies are being tested (Dita et al., 2018; Pegg et al., 2019; Thangavelu et al., 2020). Besides the cultural practices mentioned above, combinations of chemical and biological control measures have been tested to keep Foc infection at bay. Chemical control measures, such as fungicides, inhibit Foc infections under laboratory and greenhouse conditions (Nel et al., 2007); however, it remains unclear if these chemicals will function under field conditions. Furthermore, the application of chemicals in the environment raises many ecological concerns that need to be addressed before any field trials.

Environmentally friendly strategies using biological control measures to control Foc have received attention lately (Bubici et al., 2019); however, effective biological control measures are far in the future. The strength of biological controls relies on incorporating several biological control measures with appropriate cultural practises in an integrated disease management framework (Bubici et al., 2019). However, whilst these frameworks provide exciting prospects for controlling plant diseases such as Foc in the field, they are difficult to implement rigorously by many producers in developing countries such as Colombia. Therefore, the development of banana varieties resistant to Foc TR4 infections is the most promising strategy for disease control. However, despite the various trials currently taking place, it has been difficult to generate commercially accepted banana varieties with significant resistances to Foc TR4 (Dita et al., 2018; Zhang et al., 2018; Sun et al., 2019; Chen et al., 2019). Controlling Foc TR4 in the field is full of complicated obstacles, yet it is crucial that more research is conducted on the control of this pathogen because it will devastate the economy of Colombia and other banana producing countries across the globe if allowed to spread.

\section{PHYTOPHTHORA PALMIVORA}

The genus Phytophthora belongs to the family of oomycetes and comprises a great number of plant pathogenic species that seriously impede agricultural production worldwide (Erwin and Ribeiro, 1996; Ho, 2018). P. palmivora is particularly damaging in tropical and sub-tropical regions, causing root, bud, and fruit rotting diseases in several tropical crops such as cocoa, oil palm, rubber, papaya, cassava, coconut, mango, and citrus (Evangelisti et al., 2017). In Colombia, $P$. palmivora generates devastating effects on the production of oil palm (Torres et al., 2016; MaizatulSuriza et al., 2019). However, this article focused on the effects of this pathogen on cocoa production because production of this crop is crucial for the social development of Colombia, where the effects of $P$. palmivora on cocoa production are largely unknown. A study developed over three years (2010-12) on a production farm in the Antioquia region showed that this pathogen consistently caused cocoa losses of more than $70 \mathrm{~kg} \mathrm{ha}^{-1}$ year $^{-1}$ (valued at approximately USD\$82.6) (Ramírez, 2016). Despite having an area of over 666,000 ha, Colombian cocoa growers could not meet the domestic demand of 52,000 $\mathrm{t}$ in 2010 (generating a production deficit of $22.95 \%$ ) because of low production yields (Rodríguez and Vera, 2015). Cocoa production in Colombia increased in 2018, with 52,743 t of cocoa beans, accounting for $0.1 \%$ of agricultural production (FAO, 2018). Nevertheless, low cocoa production yields in Colombia remains. However, regardless of the low yields, cocoa production is seen as a priority in Colombia because it is a good replacement for illegal cocaine production (The Bogota Post, 2017; Zaragovia, 2018).

P. palmivora can infect several cocoa plant tissues including stems, flowers, and leaves (Marelli et al., 2019), but the principal symptom is water-soaked lesions on the pod that are related to the pathogen infection process (Fig. 3). Under optimal conditions, coffee coloured necrotic lesions will appear 3-5 d post infection, and, after 10-14 d, the entire pod, including the cocoa beans, is infected. Infected pods remain in the tree and are a source of inoculum for approximately 3 years (Rodríguez and Vera, 2015).

Current methods for controlling $P$. palmivora include cultural, biological, and chemical control, along with the deployment of resistant cocoa varieties (Rodríguez and Vera, 2015). Cultural, biological and chemical control strategies are important but are normally insufficient and incur economic and 
environmental costs. Thus, deployment of resistant cocoa varieties is possibly the best strategy to control Phytophthora infections in the field (Surujdeo-Maharaj et al., 2001). However, the search for effective resistances in cocoa has been a slow process because of the P. palmivora complex hemibiotrophic lifecycle, as well as the lack of in-depth molecular knowledge on the interaction between P. palmivora and cocoa plants (Rodríguez and Vera, 2015).

P. palmivora, like many other Phytophthtora species, has an hemibiotrophic lifecycle. Its predominant asexual lifecycle begins with the adhesion of motile zoospores to the host tissue, followed by encystment and germ tube formation (Judelson and Blanco, 2005; Evangelisti et al., 2017). Using entry structures called appressoria, Phytophthtora enters host tissues and generates an apoplastic hyphal network. Simultaneously, structures called haustoria are formed close to the plant cell, allowing for the acquisition of nutrients by Phytopththora and for the delivery of pathogen effectors into the host cells (Petre and Kamoun, 2014). All this occurs during the biotrophic stage of infection, which is then followed by host tissue necrosis and the production of sporangia in the necrotrophic stage of infection (Hardham, 2007).

This infection process occurs in the context of an evolutionary battle between plants and their pathogens, where plants try do deploy resistance mechanisms, and pathogens try to avoid them - achieving virulence by secreting effector molecules into the host cell (Jones and Dangl, 2006). Hence, the identification and characterisation of core effectors, which are deployed by $P$. palmivora in Colombia to surpass the immunity of cocoa plant varieties, could be extremely useful in deploying effector-aided resistant breeding that is less time consuming and more durable than conventional breeding strategies (Evangelisti et al., 2017). These effector studies could be aided by a recent study that redefined the genomic structure of P. palmivora, allowing for the identification of several new effectors from this pathogen (Morales-Cruz et al., 2020).

In conclusion, cocoa is a crop that could greatly change Colombian agriculture and society in coming decades if good production yields are achieved. Thus, it is extremely important that further studies are conducted on P. palmivora's impact on Colombian cocoa production. Furthermore, it is crucial that innovative and environmentally friendly strategies are developed to efficiently control $P$. palmivora infections in Colombia.

\section{HEMILEIA VASTATRIX}

Hemileia consists of a genus of biotrophic rust fungi, where the most studied species is $H$. vastatrix because
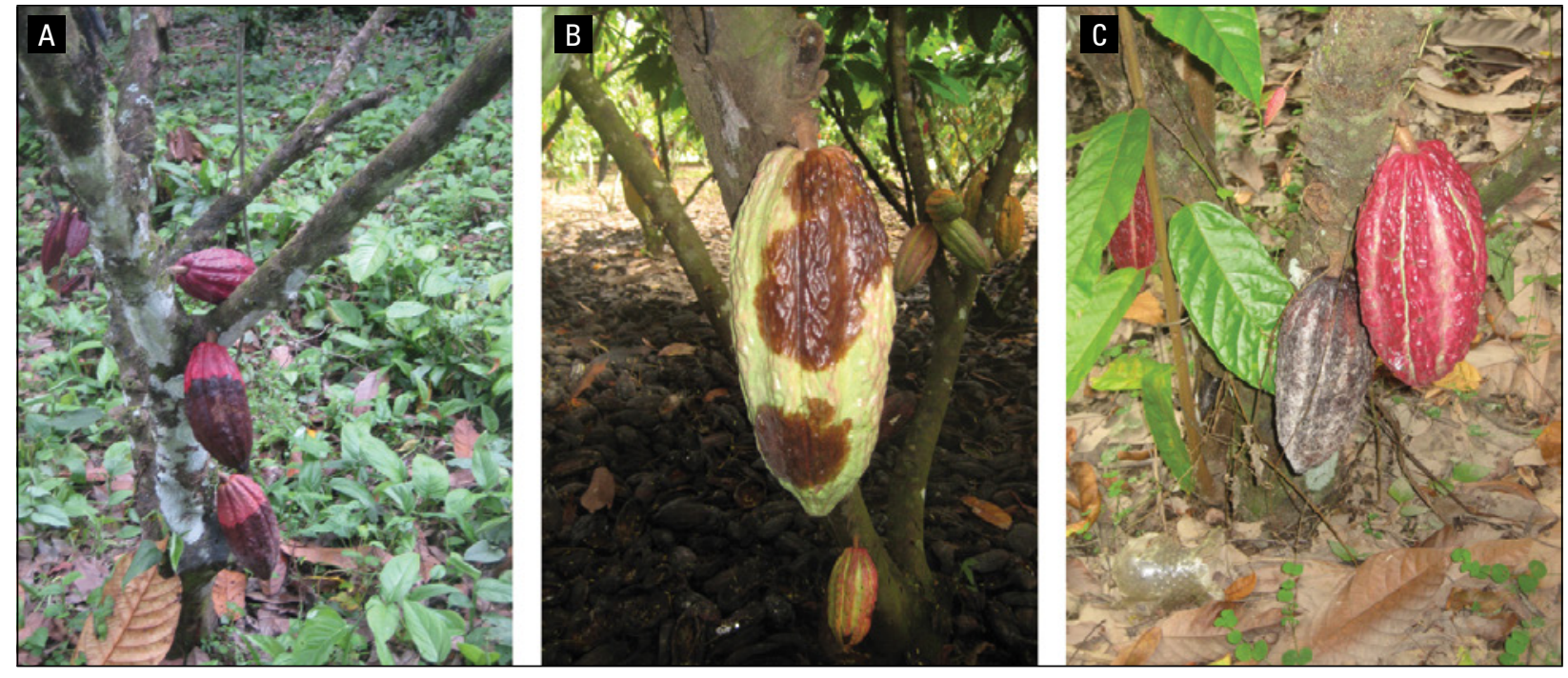

Figure 3. Symptoms of Phytophthora palmivora infection in cocoa plants grown in Colombia. Characteristic coffee-colored necrotic lesions caused by $P$. palmivora infection can be observed in cocoa pods grown in Colombia. Source: $L$. Rodríguez-Polanco, Colombian Corporation for Agricultural Research (AGROSAVIA). 
of its capacity to infect and cause economic losses on coffee plantations worldwide (Kushalappa and Eskes, 1989; McCook and Vandermeer, 2015). H. vastatrix causes the coffee leaf rust disease, first reported in Sri Lanka and Southern India in 1869. Today, coffee leaf rust is considered the major threat to coffee production worldwide (McCook and Vandermeer, 2015; Talhinhas et al., 2017).

Coffee has great economic and social value and is produced in more than 70 countries - many of which suffer from poverty with over $10 \%$ of their population living in extreme poverty (defined as earning less than USD $\$ 1.25$ a day) (Ponte, 2002; FAO, 2015). In 2019 , Colombia was the third largest coffee producer worldwide with a production of 885,120 t, behind only Brazil (3009402 t) and Vietnam (1,683,971 t) (FAO, 2019). In the Colombian agricultural sector, coffee production was shown to be the most valuable agricultural product, accounting for $17.3 \%$ of the agricultural value despite accounting for only, approximately, $1 \%$ of agricultural production in Colombia by weight (Lau et al., 2013; FAO, 2018). However, this importance could be dramatically increased if higher yields of production were achieved. Colombian production yields of coffee were 8,464 hg/ha in 2014; whilst productions for Brazil and Vietnam were 14,215 and 24,991 hg/ha, respectively (FAO, 2015).

The low yields in coffee production in Colombia are probably caused by a vast number of factors, including some that have a complicated social nature. Nevertheless, coffee production yields could be greatly increased by better management of coffee diseases, such as coffee leaf rust (Avelino et al., 2015). Whilst symptoms of $H$. vastatrix infection can be minimal, under the right conditions, these symptoms can become more acute - posing a serious threat to coffee production. In extreme cases, this can lead to a loss of fruits before harvest. When this occurs, it is considered an epidemic - such as occurred in Colombia in 1987-88 and 2008-11. These epidemics are associated with specific climatic factors, such as increased rainfalls and abnormal temperatures, and cause severe

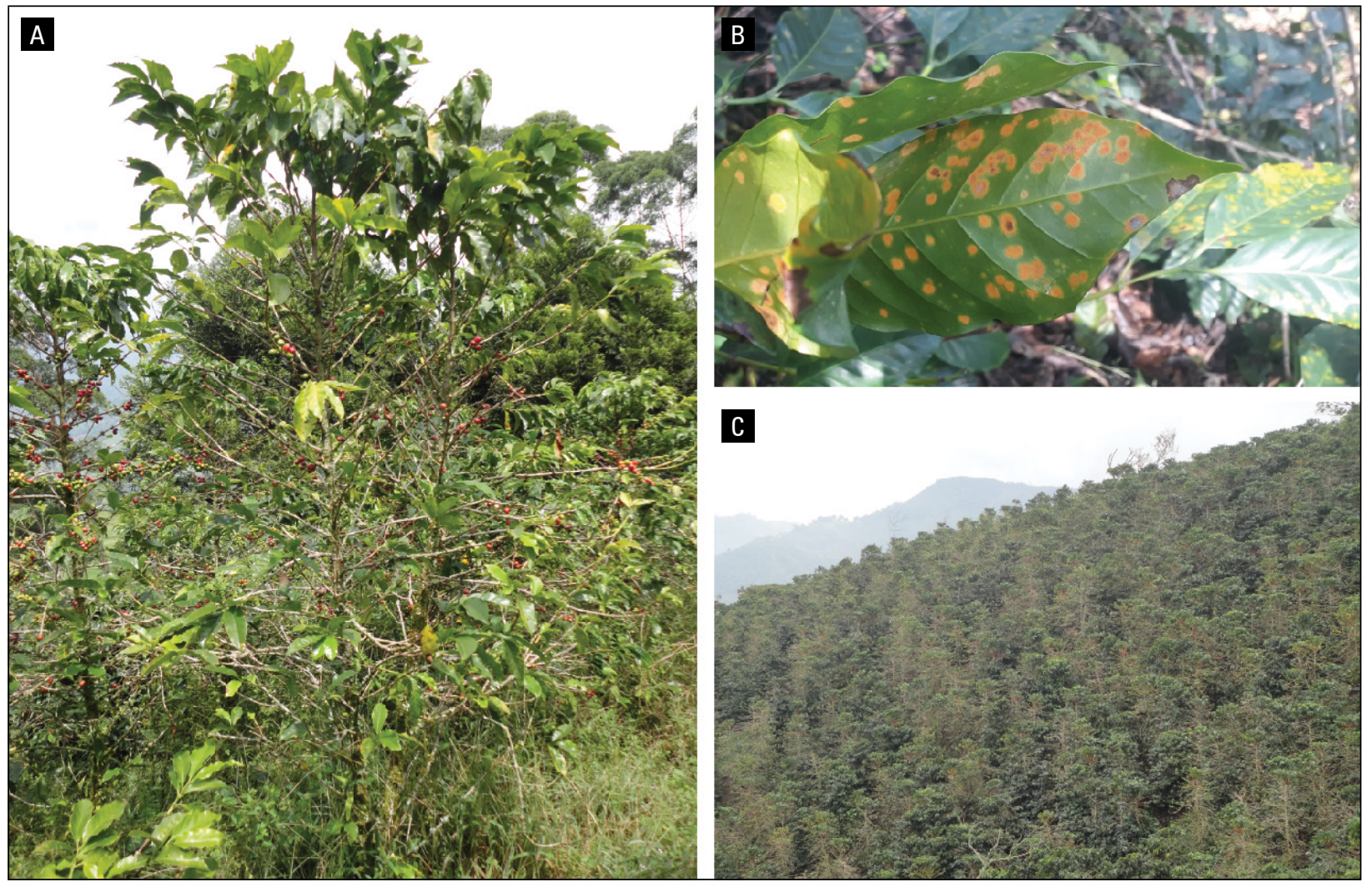

Figure 4. Symptoms of Hemileia vastatrix infection in coffee plants grown in Colombia. A, defoliation; B, distinctive yelloworange powdery lesions on the abaxial leaf surfaces; $C$, extensive damage caused by $H$. vastatrix on a coffee plantation in Colombia. Source: J.S. Márquez. 
losses in coffee production yields. For example, between 2008-11, coffee production was reduced by an average of $31 \%$ from production in 2007 (Avelino et al., 2015). Thus, it is extremely important to understand and predict these epidemics so effects can be mitigated, especially since there are likely to be increases in these climatic conditions as the result of climate change.

There is a clear need to understand $H$. vastatrix infections to predict and prevent coffee leaf rust outbreaks. However, knowledge on infection mechanisms underpinning the disease caused by this biotrophic rust fungal species remains elusive. The infection process in susceptible plants has been reported to start with the differentiation of an appressoria over the stomata and a consequent penetration of leaves by an infection hypha. These infection hyphae subsequently form haustorial mother cells that break plant cell walls, leading to the formation of the haustorium. After intense intracellular hyphal growth, infection culminates in the production of distinctive yelloworange powdery lesions on the abaxial leaf surface (Fig. 4; Ramiro et al., 2009). While the infection cycle of $H$. vastatrix is relatively well described, the molecular mechanisms underlying this infection process remain poorly understood. Like many other plant pathogenic fungi, $H$. vastatrix surpasses plant immunity by delivering effector proteins into the host cells. Genome sequencing efforts have identified hundreds of candidate effector proteins encoded in the genome of $H$. vastatrix; however, the functional roles of these effectors have not been well-described (Ramiro et al., 2009; Porto et al., 2019). Effectors from plant pathogens can be recognized by plant resistant proteins, which enhance the plant defense response - following a gene-to-gene model (Van Der Biezen and Jones, 1998; Cristancho et al., 2014). Thus, increased knowledge on the effector repertoire of $H$. vastatrix, and resistant proteins encoded by resistant coffee plants could be of extreme importance to resistance breeding efforts for coffee plants. Despite many efforts and the generation of multiple new cultivars using current techniques, resistance is always evaded by rapidly evolving pathogen strains; this increased repertoire of effector and resistance proteins could play a role in outpacing adaption of the pathogen and maintaining a high level of overall resistance (Zambolim, 2016).

Current measures used in Colombia to counteract $H$. vastatrix infections involve huge efforts planting cultivars with increased resistance, implementation of early detection strategies in the field, and preventive deployment of fungicides (Avelino et al., 2015). Nonetheless, without increased insights on the molecular mechanisms underlying this plant-pathogen interaction, a durable solution to protect coffee production in Colombia and worldwide remains elusive.

\section{CONCLUSION}

The production of food crops in Colombia is constantly threatened by a vast range of plant pests and diseases. This review looked at four plant diseases that are likely to greatly hamper Colombian agricultural production in the coming decades. Besides the economic issues regarding crop losses associated with these pathogens, these pathogens will also have huge social impacts because they affect crops that provide basic income for a vast number of small-scale producers. Hence, solutions to impede the devastating effects of these pathogens are of paramount importance.

For each of the pathogens analyzed in this review, different strategies to fight their effects should be considered. However, there is a common need to gain a deeper understanding of the molecular basis of their infection processes. This increased knowledge could translate into the deployment of more durable plant resistance in the field. Moreover, excessive use of agrochemicals that present several environmental issues could be avoided. Therefore, governments and governmental institutions in developing countries, such as Colombia, should note the critical importance of investing in research on plant pathology. While durable resistance is pursued, immediate measures should be put in place to combat crop diseases. These measures vary but should always include efforts to educate agricultural producers, along with a national-level implementation of integrated strategies that control the incidence and dispersal of pests, without compromising the economic and ecological viability of agricultural production.

We are still far from understanding the plant-pathogen interactions for the diseases mentioned above, and perhaps even farther away from making the social changes needed for this knowledge to be applied in the field, yet we hope that this review will raise awareness of the urgency to integrate biological, economic, and social sciences to face the challenge of food security in both Colombia and the rest of the world. 
Conflict of interests: The manuscript was prepared and reviewed with the participation of the authors, who declare that there exists no conflict of interest that puts at risk the validity of the presented results.

\section{BIBLIOGRAPHIC REFERENCES}

Abrahamian, P., S. Timilsina, G.V. Minsavage, N. Potnis, J.B. Jones, E.M. Goss, and G.E. Vallad. 2019. Molecular epidemiology of Xanthomonas perforans Outbreaks in tomato plants from transplant to field as determined by single-nucleotide polymorphism analysis. Appl. Environ. Microbiol. 85, e01220-19. Doi: 10.1128/ AEM.01220-19

Álvarez, E. 2006 Enfermedades limitantes de la yuca. Consorcio Latinoamericano y del Caribe de Apoyo a la Investigación y Desarrollo de la Yuca (CLAYUCA); Centro Internacional de Agricultura Tropical (CIAT), Cali, Colombia.

Arrieta-Ortiz, M.L., L.M. Rodríguez-R., Á.L. Pérez-Quintero, L. Poulin, A.C. Díaz, N. Arias, C. Trujillo, M. Restrepo, R. Bart, J. Boch, T. Boureau, A. Darrasse, P. David, T.D. Bernonville, P. Fontanilla, L. Gagnevin, F. Guérin, M.-A. Jacques, E. Lauber, P. Lefeuvre, C. Medina, E. Medina, N. Montenegro, A. Muñoz, L.D. Noël, J.F. Ortiz, D. Osorio, C. Pardo, P.B. Patil, S. Poussier, O. Pruvost, I. Robène-Soustrade, R.P. Ryan, J. Tabima, O.G. Urrego, C. Vernière, S. Carrere, V. Verdier, B. Szurek, S. Restrepo, C. López, and R. Koebnik. 2013. Genomic survey of pathogenicity determinants and VNTR markers in the cassava bacterial pathogen Xanthomonas axonopodis pv. Manihotis strain CIO151. PLoS ONE 8(11), e79704. Doi: 10.1371/journal.pone.0079704

Avelino, J., M. Cristancho, S. Georgiou, P. Imbach, L. Aguilar, G. Bornemann, P. Läderach, F. Anzueto, A.J. Hrus$\mathrm{ka}$, and C. Morales. 2015. The coffee rust crises in Colombia and Central America (2008-2013): impacts, plausible causes and proposed solutions. Food Sec. 7 , 303-321. Doi: 10.1007/s12571-015-0446-9

Ávila, K. and H.M. Romero. 2017. Plant responses to pathogen attack: molecular basis of qualitative resistance. Rev. Fac. Nac. Agron. Medellin 70(2), 8225-8235. Doi: 10.15446/rfna.v70n2.64526

Bansal, K., S. Midha, S. Kumar, and P. Patil. 2017. Ecological and evolutionary insights into Xanthomonas citri pathovar diversity. Appl. Environ. Microbiol. 83, e0299316. Doi: 10.1128/AEM.02993-16

Bart, R., M. Cohn, A. Kassen, E.J. McCallum, M. Shybut, A. Petriello, K. Krasileva, D. Dahlbeck, C. Medina, T. Alicai, L. Kumar, L.M. Moreira, J.R. Neto, V. Verdier, M.A. Santana, N. Kositcharoenkul, H. Vanderschuren, W. Gruissem, A. Bernal, and B.J. Staskawicz. 2012. High-throughput genomic sequencing of cassava bacterial blight strains identifies conserved effectors to target for durable resistance. Proc. Natl. Acad. Sci. USA 109(28), 1972-1979. Doi: 10.1073/pnas.1208003109
Bernal-Galeano, V., J.C. Ochoa, C. Trujillo, L. Rache, A. Bernal, and C.A. López. 2018. Development of a multiplex nested PCR method for detection of Xanthomonas axonopodis pv. manihotis in cassava. Trop. Plant Pathol. 43, 341-350. Doi: 10.1007/s40858-018-0214-4

Boher, B. and V. Verdier. 1994. Cassava bacterial blight in Africa: the state of knowledge and implications for designing control strategies. Afr. Crop Sci. J. 2, 505-509.

Bubici, G., M. Kaushal, M.I. Prigigallo, C. Gómez-Lama Cabanás, and J. Mercado-Blanco. 2019. Biological control agents against Fusarium wilt of banana. Front. Microbiol. 10, 616. Doi: 10.3389/fmicb.2019.00616

Büttner, D. and S.Y. He. 2009. Type III protein secretion in plant pathogenic bacteria. Plant Physiol. 150(4), 16561664. Doi: 10.1104/pp.109.139089

Cadavid López, L.F. 2006. Aspectos tecnológicos sobre producción de yuca. Consorcio Latinoamericano y del Caribe de Apoyo a la Investigación y Desarrollo de la Yuca (CLAYUCA); Centro Internacional de Agricultura Tropical (CIAT), Cali, Colombia.

Chakraborty, S. and A. Newton. 2011. Climate change, plant diseases and food security: an overview. Plant Pathol. 60, 2-14. Doi: 10.1111/j.1365-3059.2010.02411.x

Chavarriaga-Aguirre, P., A. Brand, A. Medina, M. Prías, R. Escobar, J. Martinez, P. Díaz, C. López, W.M. Roca, and J. Tohme. 2016. The potential of using biotechnology to improve cassava: a review. In Vitro Cell. Dev. Biol.-Plant 52, 461-478. Doi: 10.1007/s11627-016-9776-3

Chen, A., J. Sun, A. Matthews, L. Armas-Egas, N. Chen, S. Hamill, L.T.T. Tran-Nguyen, J. Batley, and E.A.B. Aitken. 2019. Assessing variations in host resistance to Fusarium oxysporum $\mathrm{f}$ sp. cubense Race 4 in Musa species, with a focus on the subtropical Race 4 . Front. Microbiol. 10, 1062. Doi: 10.3389/fmicb.2019.01062

Cristancho, M.A., D.O. Botero-Rozo, W. Giraldo, J. Tabima, D.M. Riaño-Pachón, C. Escobar, Y. Rozo, L.F. Rivera, A. Durán, S. Restrepo, T. Eilam, Y. Anikster, and A.L. Gaitán. 2014. Annotation of a hybrid partial genome of the coffee rust (Hemileia vastatrix) contributes to the gene repertoire catalog of the Pucciniales. Front. Plant Sci. 5, 594. Doi: 10.3389/fpls.2014.00594

DANE, Departamento Administrativo Nacional de Estadística of Colombia. 2016. Boletín mensual insumos y factores asociados a la producción agropecuaria: El cultivo de la yuca (Manihot esculenta Crantz). Report No. 46. Bogota.

Dean, R., J. Van Kan, Z. Pretorius, K. Hammond-Kosack, A. Di Pietro, P. Spanu, J.J. Rudd, M. Dickman, R. Kahmann, J. Ellis, and G.D. Foster. 2012. The top 10 fungal pathogens in molecular plant pathology. Mol. Plant Pathol. 13, 414-430. Doi: 10.1111/j.1364-3703.2011.00783.x

Di Pietro, A., M.P. Madrid, Z. Caracuel, J. Delgado-Jarana, and M.I.G. Roncero. 2003. Fusarium oxysporum: exploring the molecular arsenal of a vascular wilt 
fungus. Mol. Plant Pathol. 4(5), 315-325. Doi: 10.1046/j.1364-3703.2003.00180.x

Díaz, P.A., M. Herrera, J.C. Ochoa, A. Medina, M.A. Prías, V. Verdier, P. Chavarriaga, and C.E. López. 2018. The overexpression of RXam1, a cassava gene coding for an RLK, confers disease resistance to Xanthomonas axonopodis pv. manihotis. Planta 247, 1031-1042. Doi: 10.1007/s00425-018-2863-4

Dita, M., M. Barquero, D. Heck, E.S.G. Mizubuti, and C.P. Staver. 2018. Fusarium wilt of banana: Current knowledge on epidemiology and research needs toward sustainable disease management. Front. Plant Sci. 9, 1468. Doi: $10.3389 /$ fpls.2018.01468

Donatelli, M., R. Magarey, S. Bregaglio, L. Willocquet, J. Whish, and S. Savary. 2017. Modelling the impacts of pests and diseases on agricultural systems. Agric. Syst. 155, 213-224. Doi: 10.1016/j.agsy.2017.01.019

Drenth, A. and D.I. Guest. 2016. Fungal and oomycete diseases of tropical tree fruit crops. Annu. Rev. Phytopathol. 54, 373-395. Doi: 10.1146/annurevphyto-080615-095944

Dusunceli, F. 2017. Global programme on banana Fusarium wilt disease: Protecting banana production from the disease with focus on tropical Race 4 (TR4). FAO, Rome.

Erwin, D.C. and O.K. Ribeiro. 1996. Phytophthora diseases worldwide. APS Press, St. Paul, MN.

Evangelisti, E., A. Gogleva, T. Hainaux, M. Doumane, F. Tulin, C. Quan, T. Yunusov, K. Floch, and S. Schornack. 2017. Time-resolved dual transcriptomics reveal early induced Nicotiana benthamiana root genes and conserved infection-promoting Phytophthora palmivora effectors. BMC Biol. 15, 39. Doi: 10.1186/ s12915-017-0379-1

Fanou, A., V. Zinsou, and K. Wydra. 2018. Cassava bacterial blight: A devastating disease of cassava. pp. 13-36. In: Waisundara, V.Y. (eds.). Cassava. IntechOpen, New Delhi. Doi: 10.5772/intechopen.71527

FAO. 2006. Food security. FAO Policy Brief No. 2. In: http:// www.fao.org/fileadmin/templates/faoitaly/documents/pdf/pdf_Food_Security_Cocept_Note.pdf; consulted: March, 2021.

FAO. 2015. FAO statistical pocketbook coffee 2015. Rome.

FAO. 2018. FAOSTAT statistical database. Crops. In: http://www.fao.org/faostat/en/\#home; consulted: June, 2020.

FAO. 2019. FAOSTAT statistical database. In: http://www. fao.org/faostat/en/\#home; consulted: April, 2021.

García-Bastidas, F.A., J.C. Quintero-Vargas, M. Ayala-Vasquez, T. Schermer, M.F. Seidl, M. Santos-Paiva, A.M. Noguera, C. Aguilera-Galvez, A. Wittenberg, R. Hofstede, A. Sørensen, and G.H.J. Kema. 2020. First report of Fusarium wilt tropical Race 4 in Cavendish bananas caused by Fusarium odoratissimum in
Colombia. Plant Dis. 104(3), 994-994. Doi: 10.1094/ PDIS-09-19-1922-PDN

Graham, F. 2019. Daily briefing: A devastating banana fungus just reached the Americas. Nature, 20 August. Doi: 10.1038/d41586-019-02506-7

Hardham, A. 2007. Cell biology of plant-oomycete interactions. Cell. Microb. 9(1), 31-39. Doi: 10.1111/j.1462-5822.2006.00833.x

Hayward, A.C. 1993. The hosts of Xanthomonas. pp. 1-119. In: Swings, J. and L. Civerolo (eds.). Xanthomonas. Springer, Dordrecht, The Netherlands. Doi: 10.1007/978-94-011-1526-1

Hennessy, C., G. Walduck, A. Daly, and A. Padovan. 2005. Weed hosts of Fusarium oxysporum $\mathrm{f}$. sp. Cubense tropical Race 4 in northern Australia. Australas. Plant Pathol. 34, 115-117. Doi: 10.1071/ap04091

Hernandez, J.M., R. Laberry, and J.C. Lozano. 1986. Observations on the effect of inoculating cassava (Manihot esculenta) plantlets with fluorescent pseudomona. J. Phytopathol. 117(1), 17-25. Doi: 10.1111/j.14390434.1986.tb04355.x

Herrera, M., D. Portillo, M.A. Pulido, P.A. Diaz, and C.E. López. 2018. Estudio de la expresión de genes que codifican para putativas proteínas PR en yuca (Manihot esculenta Crantz). Acta Biol. Colomb. 23(3), 242-252. Doi: 10.15446/abc.v23n3.70868

Ho, H.H. 2018. The taxonomy and biology of Phytophthora and Pythium. J. Bacteriol. Mycol.: Open Access 6(1), 40-45. Doi: 10.15406/jbmoa.2018.06.00174

Howeler, R., N. Lutaladio, and G. Thomas. 2013. Save and grow: Cassava. A guide to sustainable production intensification. Rome.

Hudson, R. 2010. Colombia a country study. Federal Research Division, Library of Congress, Washington, DC.

Jarvis, A., J. Ramirez-Villegas, B.V. Herrera, and C. Navarro-Racines. 2012. Is cassava the answer to African climate change adaptation? Trop. Plant Biol. 5, 9-29. Doi: $10.1007 / \mathrm{s} 12042-012-9096-7$

Jones, J. and J. Dangl. 2006. The plant immune system. Nature 444, 323-329. Doi: 10.1038/nature05286

Judelson, H.S. and F.A. Blanco. 2005. The spores of Phytophthora: weapons of the plant destroyer. Nature Rev. Microb. 3, 47-58. Doi: 10.1038/nrmicro1064

Jorge, V., M.A. Fregene, M.C. Duque, M.W. Bonierbale, J. Tohme, and V. Verdier. 2000. Genetic mapping of resistance to bacterial blight disease in cassava (Manihot esculenta Crantz). Theor. Appl. Genet. 101, 865-872. Doi: $10.1007 / \mathrm{s} 001220051554$

Kamoun, S., O. Furzer, J. Jones, H. Judelson, G. Ali, R. Dalio, S.G. Roy, L. Schena, A. Zambounis, F. Panabières, D. Cahill, M. Ruocco, A. Figueiredo, X.-R. Chen, J. Hulvey, R. Stam, K. Lamour, M. Gijzen, B.M. Tyler, N.J. Grünwald, M.S. Mukhtar, D.F.A. Tomé, M. 
Tör, G. Van Den Ackerveken, J. McDowell, F. Daayf, W.E. Fry, H. Lindqvist-Kreuze, H.J.G. Meijer, B. Petre, J. Ristaino, K. Yoshida, P.R.J. Birch, and F. Govers. 2015. The top 10 oomycete pathogens in molecular plant pathology. Mol. Plant Pathol. 16, 413-434. Doi: 10.1111/mpp.12190

Kpemoua, K., B. Boher, M. Nicole, P. Calatayud, and J.P. Geiger. 1996. Cytochemistry of defense responses in cassava infected by Xanthomonas campestris pv. manihotis. Can. J. Microbiol. 42(11), 1131-1143. Doi: 10.1139/ m96-145

Kushalappa, A.C. and A.B. Eskes. 1989. Advances in coffee rust research. Ann. Rev. Phytopathol. 27, 503-531. Doi: 10.1146/annurev.py.27.090189.002443

Lau, C., A. Jarvis, and J. Ramírez. 2013. Colombian agriculture: Adapting to climate change. CIAT, Cali, Colombia.

Lin, Z.J., N.J. Taylor, and R. Bart. 2019. Engineering disease-resistant cassava. Cold Spring Harb. Perspect. Biol. 11, a034595. Doi: 10.1101/cshperspect.a034595

Lombard, L., M. Sandoval-Denis, S.C. Lamprecht, and P.W. Crous. 2019. Epitypification of Fusarium oxysporum - clearing the taxonomic chaos. Persoonia - Mol. Phylog. Evol. Fungi 43, 1-47. Doi: 10.3767/ persoonia.2019.43.01

López, C. and A. Bernal. 2012. Cassava bacterial blight: Using genomics for the elucidation and management of an old problem. Trop. Plant Biol. 5, 117-126. Doi: 10.1007/s12042-011-9092-3

Lozano, J.C. 1986. Cassava bacterial blight: A manageable disease. Plant Dis. 70, 1089-1093. Doi: 10.1094/ PD-70-1089

Lozano, J.C. and L. Sequeira. 1974. Bacterial blight of cassava in Colombia: Etiology. Phytopathology 64, 74-82. Doi: 10.1094/Phyto-64-74

Maizatul-Suriza, M., M. Dickinson, and A.S. Idris. 2019. Molecular characterization of Phytophthora palmivora responsible for bud rot disease of oil palm in Colombia. World J. Microbiol. Biotechnol. 35, 44. Doi: 10.1007/s11274-019-2618-9

Mansfield, J., S. Genin, S. Magori, V. Citovsky, M. Sriariyanum, P. Ronald, M. Dow, V. Verdier, S.V. Beer, M.A. Machado, I. Toth, G. Salmond, and G.D. Foster. 2012. Top 10 plant pathogenic bacteria in molecular plant pathology. Mol. Plant Pathol. 13(6), 614-629. Doi: 10.1111/j.1364-3703.2012.00804.x

Marelli, J.P., D.I. Guest, B.A. Bailey, H.C. Evans, J.K. Brown, M. Junaid, R.W. Barreto, D.O. Lisboa, and A.S. Puig. 2019. Chocolate under threat from old and new cacao diseases. Phytopathology 109(8), 1331-1343. Doi: 10.1094/PHYTO-12-18-0477-RVW

Marin, V.R., J.H. Ferrarezi, G. Vieira, and D.C. Sass. 2019. Recent advances in the biocontrol of Xanthomonas spp. World J. Microbiol. Biotechnol. 35, 72. Doi: 10.1007/ s11274-019-2646-5
Maryani, N., L. Lombard, Y.S. Poerba, S. Subandiyah, P.W. Crous, and G.H.J. Kema. 2019. Phylogeny and genetic diversity of the banana fusarium wilt pathogen Fusarium oxysporum f. sp. Cubense in the Indonesian centre of origin. Stud. Mycol. 92, 155-194. Doi: 10.1016/j. simyco.2018.06.003

McCook, S. and J. Vandermeer. 2015. The big rust and the red queen: Long-term perspectives on coffee rust research. Phytopathology 105(9), 1164-1173. Doi: 10.1094/PHYTO-04-15-0085-RVW

Medina, C.A., P.A. Reyes, C.A. Trujillo, J.L. Gonzalez, D.A. Bejarano, N.A. Montenegro, J.M. Jacobs, A. Joe, S. Restrepo, J.R. Alfano, and A. Bernal. 2017. The role of type III effectors from Xanthomonas axonopodis pv. manihotis in virulence and suppression of plant immunity. Mol. Plant Pathol. 19(3), 593-606. Doi: 10.1111/ mpp. 12545

Morales-Cruz, A., S. Ali, A. Minio, R. Figueroa-Balderas, J.F. García, T. Kasuga, A.S. Puig, J.-P. Marelli, B.A. Bailey, and D. Cantu. 2020. Independent whole-genome duplications define the architecture of the genomes of the devastating West African cacao black pod pathogen Phytophthora megakarya and its close relative Phytophthora palmivora. G3 Genes/Genomes/Genetics 10(7), 2241-2255. Doi: 10.1534/g3.120.401014

Nel, B., C. Steinberg, N. Labuschagne, and A. Viljoen. 2007. Evaluation of fungicides and sterilants for potential application in the management of Fusarium wilt of banana. Crop Prot. 26(7), 697-705. Doi: 10.1016/j. cropro.2006.06.008

Obigbesan, G.O. and E.O. Matuluko. 1976. Effect of potassium and bacterial blight on the yield and chemical composition of cassava cultivars. pp. 185-188. In: Cock, J., R. MacIntyre, and M. Graham (eds.). Proc. $4^{\text {th }}$ Symp. Int. Soc. Trop. Root Crops. IDRC, Ottawa; Cali, Colombia.

Ocimati, W., H. Bouwmeester, J.C.J. Groot, P. Tittonell, D. Brown, and G. Blomme. 2019. The risk posed by Xanthomonas wilt disease of banana: Mapping of disease hotspots, fronts and vulnerable landscapes. PloS ONE 14(4), e0213691. Doi: 10.1371/journal.pone.0213691

OECD, Organisation for Economic Co-operation and Development. 2015. OECD Review of Agricultural Policies: Colombia 2015. Paris.

Oerke, E.-C. 2006. Crop losses to pests. J. Agric. Sci. 144(1), 31-43. Doi: 10.1017/S0021859605005708

Ordonez, N., M.F. Seidl, C. Waalwijk, A. Drenth, A. Kilian, B.P.H.J. Thomma, R.C. Ploetz, and G.H.J. Kema. 2015. Worse comes to worst: Bananas and panama diseasewhen plant and pathogen clones meet. PloS Pathog. 11(11), e1005197. Doi: 10.1371/journal.ppat.1005197

Pattison, A.B., C.L. Wright, T.L. Kukulies, and A.B. Molina. 2014. Ground cover management alters development of Fusarium wilt symptoms in Ducasse bananas. Australas. Plant Pathol. 43, 465-476. Doi: 10.1007/ s13313-014-0296-5 
Pegg, K.G., L.M. Coates, W.T. O'Neill, and D.W. Turner. 2019. The epidemiology of Fusarium Wilt of banana. Front. Plant Sci. 10, 1395. Doi: 10.3389/fpls.2019.01395

Petre, B. and S. Kamoun. 2014. How do filamentous pathogens deliver effector proteins into plant cells? PLoS Biol. 12(2), e1001801. Doi: 10.1371/journal. pbio. 1001801

Ploetz, R.C. 2005. Panama disease: An old nemesis rears its ugly head: Part 1 . The beginnings of the banana export trades. Plant Health Prog. 6, 1. Doi: 10.1094/ PHP-2005-1221-01-RV

Ploetz, R.C. 2006. Panama disease: An old nemesis rears its ugly: Head part 2. The Cavendish era and beyond. Plant Health Prog. 7, 1. Doi: 10.1094/PHP-2006-0308-01-RV

Ploetz, R.C. 2015a. Fusarium wilt of banana. Phytopathology 105(12), 1512-1521. Doi: 10.1094/ PHYTO-04-15-0101-RVW

Ploetz, R.C. 2015b. Management of Fusarium wilt of banana: A review with special reference to tropical Race 4. Crop Prot. 73, 7-15. Doi: 10.1016/j.cropro.2015.01.007

Ponte, S. 2002. The 'Latte Revolution'? Regulation, markets and consumption in the global coffee chain. World Dev. 30(7), 1099-1122. Doi: 10.1016/ S0305-750X(02)00032-3

Porto, B.N., E.T. Caixeta, S.M. Mathioni, P.M.P. Vidigal, L. Zambolim, E.M. Zambolim, N. Donofrio, S.W. Polson, T.A. Maia, C. Chen, M. Adetunji, B. Kingham, R.J.D. Dalio, and M.L.V. Resende. 2019. Genome sequencing and transcript analysis of Hemileia vastatrix reveal expression dynamics of candidate effectors dependent on host compatibility. PloS ONE 14(4), e0215598. Doi: 10.1371/journal.pone.0215598

Qin, S., C. Ji, Y. Li, and Z. Wang. 2017. Comparative transcriptomic analysis of Race 1 and Race 4 of Fusarium oxysporum f. sp. cubense induced with different carbon sources. G3 Genes/Genomes/Genetics 7(7), 21252138. Doi: $10.1534 / g 3.117 .042226$

Rache, L., L. Blondin, C. Flores, C. Trujillo, B. Szurek, S. Restrepo, R. Koebnik, A. Bernal, and C. Vernière. 2019. An optimized microsatellite scheme for assessing populations of Xanthomonas phaseoli pv. Manihotis. Phytopathology 109(5), 859-869. Doi: 10.1094/ PHYTO-06-18-0210-R

Ramírez, J.G. 2016. Pérdidas económicas asociadas a la pudrición de la mazorca del cacao causada por Phytophthora spp., y Moniliophthora roreri (Cif y Par) Evans et al., en la hacienda Theobroma, Colombia. Rev. Prot. Veg. 31, 42-49.

Ramiro, D.A., J. Escoute, A.S. Petitot, M. Nicole, M.P. Maluf, and D. Fernandez. 2009. Biphasic haustorial differentiation of coffee rust (Hemileia vastatrix Race II) associated with defence responses in resistant and susceptible coffee cultivars. Plant Pathol. 58, 944-955. Doi: 10.1111/j.1365-3059.2009.02122.x
Raza, A., A. Razzaq, S.S. Mehmood, X. Zou, X. Zhang, Y. Lv, and J. Xu. 2019. Impact of climate change on crops adaptation and strategies to tackle its outcome: A review. Plants 8(2), 34. Doi: 10.3390/plants8020034

Restrepo, S., M.C. Duque, and V. Verdier. 2000. Characterization of pathotypes among isolates of Xanthomonas axonopodis pv. manihotis in Colombia. Plant Pathol. 49(6), 680-687. Doi: 10.1046/j.1365-3059.2000.00513.x

Restrepo, S., C.M. Velez, M.C. Duque, and V. Verdier. 2004. Genetic structure and population dynamics of Xanthomonas axonopodis pv. manihotis in Colombia from 1995 to 1999. Appl. Environ. Microbiol. 70, 255-261. Doi: 10.1128/AEM.70.1.255-261.2004

Rodríguez, E. and A.G. Vera. 2015. Identificación y manejo de la pudrición parda de la mazorca (Phytophthora sp.) en cacao. Corpoica, Mosquera, Colombia.

Ryan, R., F. Vorhölter, N. Potnis, J. Jones, M. Van Sluys, A. Bogdanove, and M. Dow. 2011. Pathogenomics of Xanthomonas: understanding bacterium-plant interactions. Nature Rev. Microb. 9, 344-355. Doi: 10.1038/ nrmicro2558

Soto, J., R.E. Mora, F. Calle, and C.E. López. 2017. OTL identification for cassava bacterial blight resistance under natural infection conditions. Acta Biol. Colomb. 22(1), 19-26. Doi: 10.15446/abc.v22n1.57951

Sun, J., J. Zhang, H. Fang, L. Peng, S. Wei, C. Li, S. Zheng, and J. Lu. 2019. Comparative transcriptome analysis reveals resistance-related genes and pathways in Musa acuminata banana 'Guijiao 9' in response to Fusarium wilt. Plant Physiol. Biochem. 141, 83-94. Doi: 10.1016/j.plaphy.2019.05.022

Surujdeo-Maharaj, S., P. Umaharan, and A.D. Iwaro. 2001. A study of genotype-isolate interaction in cacao (Theobroma cacao L.): Resistance of cacao genotypes to isolates of Phytophthora palmivora. Euphytica 118, 295303. Doi: 10.1023/A:1017516217662

Talhinhas, P., D. Batista, I. Diniz, A. Vieira, D.N. Silva, A. Loureiro, S. Tavares, A.P. Pereira, H.G. Azinheira, L. Guerra-Guimarães, V. Várzea, and M.C. Silva. 2017. The coffee leaf rust pathogen Hemileia vastatrix: one and a half centuries around the tropics. Mol. Plant Pathol. 18(8), 1039-1051. Doi: 10.1111/mpp.12512

Thangavelu, R., M. Loganathan, R. Arthee, M. Prabakaran, and S. Uma. 2020. Fusarium wilt: a threat to banana cultivation and its management. CAB Rev. 15, 004. Doi: 10.1079/PAVSNNR202015004

The Bogota Post. 2017. From cocaine to cacao: Vichada's transition to legal crops. In: https://thebogotapost.com/ coca-cacao-vichadas-transition-legal-crops/21799/; consulted: June, 2020.

Torres, G.A., G.A. Sarria, G. Martinez, F. Varon, A. Drenth, and D.I. Guest. 2016. Bud rot caused by Phytophthora palmivora: A destructive emerging disease of oil palm. Phytopathology 106(4), 320-329. Doi: 10.1094/ PHYTO-09-15-0243-RVW 
Trujillo, C.A., J.C. Ochoa, M.F. Mideros, S. Restrepo, C. López, and A. Bernal. 2014. A complex population structure of the cassava pathogen Xanthomonas axonopodis pv. manihotis in recent years in the Caribbean Region of Colombia. Environ. Microbiol. 68, 155-167. Doi: 10.1007/s00248-014-0411-8

Van Der Biezen, E.A. and J.D.G. Jones. 1998. Plant disease-resistance proteins and the gene-for-gene concept. Trends Biochem. Sci. 23(12), 454-456. Doi: 10.1016/S0968-0004(98)01311-5

Verdier, V., S. Restrepo, G. Mosquera, V. Jorge, and C. Lopez. 2004. Recent progress in the characterization of molecular determinants in the Xanthomonas axonopodis pv. manihotis-cassava interaction. Plant Mol. Biol. 56, 573-584. Doi: 10.1007/s11103-004-5044-8

Wang, M., Y. Sun, G. Sun, X. Liu, L. Zhai, O. Shen, and S. Guo. 2015. Water balance altered in cucumber plants infected with Fusarium oxysporum f. sp. cucumerinum. Sci. Rep. 5, 7722. Doi: 10.1038/srep07722

Wydra, K., V. Zinsou, V. Jorge, and V. Verdier. 2004. Identification of pathotypes of Xanthomonas axonopodis pv. Manihotis in Africa and detection of quantitative trait loci and markers for resistance to bacterial blight of cassava. Phytopathology 94(10), 1084-1093. Doi: 10.1094/PHYTO.2004.94.10.1084

Zambolim, L. 2016 Current status and management of coffee leaf rust in Brazil. Trop. Plant Pathol. 41, 1-8. Doi: 10.1007/s40858-016-0065-9

Zaragovia, V. 2018. From cocaine to cacao: One man's mission to save Colombia's farmers through chocolate. In: Pulitzer Center, https://pulitzercenter.org/reporting/cocaine-cacao-one-mans-mission-save-colombias-farmers-through-chocolate; consulted: June, 2020.

Zhang, H., A. Mallik, and R.S. Zeng. 2013. Control of panama disease of banana by rotating and intercropping with chinese chive (Allium Tuberosum Rottler): Role of plant volatiles. J. Chem. Ecol. 39, 243-252. Doi: 10.1007/s10886-013-0243-x

Zhang, H. and S. Wang. 2013. Rice versus Xanthomonas oryzae pv. oryzae: A unique pathosystem. Curr. Opin. Plant Biol. 16(2), 188-195. Doi: 10.1016/j.pbi.2013.02.008

Zhang, L., T. Yuan, Y. Wang, D. Zhang, T. Bai, S. Xu, Y. Wang, W. Tang, and S.-J. Zheng. 2018. Identification and evaluation of resistance to Fusarium oxysporum $\mathrm{f}$. sp. cubense tropical Race 4 in Musa acuminata Pahang. Euphytica 214, 106. Doi: 10.1007/s10681-018-2185-4 